Izabela Mleczko

Paula Pustułka

Justyna Sarnowska

Marta Buler

Uniwersytet SWPS

\title{
Nowe oblicza konfliktu ról wśród młodych Polek i Polaków w świetle łączenia rodzicielstwa ze studiami i pracą zawodową
}

DOI: http://dx.doi.org/10.18778/1733-8069.15.4.06

\begin{abstract}
Abstrakt Tematykę artykułu stanowi łączenie rodzicielstwa ze studiami i pracą zawodową, które jest wyjątkową egzemplifikacją współczesnego nakładania się ról i wyzwań wynikających z konfliktu doświadczanego przez młode osoby realizujące jednocześnie liczne, konkurencyjne względem siebie role społeczne. Jest to efekt wyłaniający się z szerszego kontekstu społecznego, w którym zdobywanie wykształcenia na poziomie wyższym jest coraz powszechniejsze wśród młodych Polek i Polaków, a w szeregach studentów nie brakuje rodziców i osób o ugruntowanej pozycji na rynku pracy. Bazą empiryczną artykułu jest materiał zebrany w badaniu jakościowym przeprowadzonym na przełomie 2017 i 2018 roku. Na potrzeby artykułu przeanalizowano 30 wywiadów z jednocześnie pracującymi i studiującymi rodzicami. Respondenci łączą lub łączyli pracę zawodową, zdobywanie dyplomu uczelni oraz wychowywanie dzieci w różnym wieku (od 0 do 15 lat). Zaprezentowane wyniki wskazują na występowanie konfliktu ról, jednocześnie pokazując zróżnicowanie i uzależnienie poczucia konfliktu od takich elementów jak płeć, wsparcie społeczne czy też instytucjonalne. Konflikt w tej analizie jest ściśle powiązany z koncepcją „chciwych instytucji”, jakimi są edukacja, rodzicielstwo i praca zawodowa. Widoczna jest również normalizacja łączenia tych trzech aspektów życia jednostki przy jednoczesnym poczuciu konieczności realizowania się na wszystkich polach.
\end{abstract}

Słowa kluczowe konflikt ról, młodzi, przejście z edukacji na rynek pracy, rodzicielstwo

Izabela Mleczko, absolwentka Uniwersytetu SWPS; specjalizuje się w zagadnieniach rynku pracy i edukacji. Jest praktykującym doradcą zawodowym młodzieży oraz dorosłych.

\section{Adres kontaktowy:}

Młodzi w Centrum LAB Uniwersytetu SWPS w Warszawie

ul. Chodakowska 19/31, 03-815 Warszawa

e-mail: imleczko@st.swps.edu.pl 
Paula Pustułka, dr, adiunkt na Wydziale Nauk Humanistycznych i Społecznych Uniwersytetu SWPS w Warszawie. W ośrodku badawczym „Młodzi w Centrum LAB” zajmuje się tematyką międzynarodowych migracji, życiem młodych ludzi, zmianami w obrębie rodziny, gender studies oraz metodologią badań jakościowych.

\section{Adres kontaktowy:}

Młodzi w Centrum LAB Uniwersytetu SWPS w Warszawie

ul. Chodakowska 19/31, 03-815 Warszawa

e-mail: ppustulka@swps.edu.pl

Justyna Sarnowska, dr, adiunkt na Wydziale Nauk Humanistycznych i Społecznych Uniwersytetu SWPS. Interesuje się procesem wchodzenia na rynek pracy i osiągania dorosłości. Bada młodych Polaków doświadczających różnych form mobilności społecznej i przestrzennej.

\section{Adres kontaktowy:}

Młodzi w Centrum LAB Uniwersytetu SWPS w Warszawie ul. Chodakowska 19/31, 03-815 Warszawa e-mail: jsarnowska@swps.edu.pl

Marta Buler, doktorantka socjologii na Uniwersytecie SWPS oraz stypendystka NCN. Prowadzi badania z zakresu wpływu migracji na kształt i funkcjonowanie rodziny. Interesuje się zagadnieniami z zakresu studiów nad rodziną oraz gender studies.

\section{Adres kontaktowy:}

Młodzi w Centrum LAB Uniwersytetu SWPS w Warszawie ul. Chodakowska 19/31, 03-815 Warszawa e-mail: mbuler@swps.edu.pl
$\mathrm{N}^{2}$ aukowe analizy i potoczne obserwacje sygnalizuja pewne rozedrganie biografii rodzinnych, edukacyjnych i zawodowych dzisiejszego pokolenia trzydziestolatków w Polsce (por. Wrzesień 2016). W drugiej dekadzie życia coraz rzadziej realizują oni sekwencję ukończenia edukacji, rozpoczęcia pracy i założenia rodziny w sposób linearny (por. Fenton, Dermott 2006), a zdecydowanie powszechniejsze jest nakładanie się ról życiowych oraz symultaniczne podejmowanie wyzwań zawodowych, edukacyjnych i rodzinnych (Sarnowska i in. 2016; Szafraniec i in. 2017). Dane statystyczne mówią o około 40\% osób, które jednocześnie studiują i pracuja, co wskazuje, że nie jest to zjawisko marginalne (Eurofound 2014; GUS 2017). Problematyka edukacji na poziomie uniwersyteckim w kontekście pracy i nowych wzorów rodzinności (Slany 2013), oddziałująca na sytuację tak zwanych studentów nietradycyjnych (Scott, Burns, Cooney 1996), stano- wi ważne zjawisko we współczesnym krajobrazie edukacyjnym i społecznym. Jest zatem zapotrzebowanie na pogłębione analizy, które w tym artykule przedstawiamy poprzez pryzmat teorii konfliktu ról (Hochschild 1997; Marshall 1998; Milkie, Peltola 1999; Bobrowicz 2007; Gregory, Milner 2009; Pustułka, Ślusarczyk 2016) oraz koncepcji „,chciwych instytucji”1 (Coser 1974; Hochschild 1997).

Głównym celem artykułu jest ukazanie nowego oblicza konfliktu ról, z jakim zmagają się współcześnie młodzi ludzie będący jednocześnie rodzicami, studentami oraz pracownikami (Wyn, Dwyer 1999) na podstawie badania przeprowadzonego wśród studentów i absolwentów Uniwersytetu SWPS. Rozważania rozpoczynamy od przedstawienia konfliktu

\footnotetext{
${ }^{1} \mathrm{~W}$ polskiej literaturze funkcjonują dwa tłumaczenia pojęcia "greedy institution", które np. Rosińska-Kordasiewicz (2008) określa „zachłannymi”, a Konecki (2018) nazywa "chciwymi”. $\mathrm{W}$ artykule stosujemy to drugie określenie.
} 
ról na tle koncepcji „chciwych instytucji” (Coser 1974). Następnie przechodzimy do zaprezentowania danych i badań określających kontekst społeczno-ekonomiczny, który niejako wymusza i normalizuje konflikt ról wśród młodych Polaków. Po przedstawieniu metodologii badania, w głównej części artykułu prezentujemy wyniki, które ilustrują postrzeganie poszczególnych ról $\mathrm{w}$ trakcie ich jednoczesnego wypełniania. Skupiamy się na definiowaniu ról przez młodych, hierarchizowaniu ich ważności, kompromisach wynikających z przyjętych założeń, a także upłciowieniu konfliktu.

\section{Konflikt ról: rama teoretyczna do badania łączenia edukacji z rodzicielstwem i pracą zawodową}

Rola jest jednym z podstawowych pojęć socjologicznych pojawiającym się $\mathrm{w}$ rozmaitych podejściach analitycznych i teoretycznych. Kluczowe dla jej współczesnej definicji było podejście strukturalne oraz interakcjonistyczne. Pierwsze z nich rozumiało role jako elementy systemowe wyposażone w zespół normatywnych praw i obowiązków (por. Dahrendorf 1973; Parsons 2009). Interakcjonizm z kolei wskazywał na ich procesualność, czyli obejmowanie, odgrywanie oraz wykonywanie roli (por. Goffman 2011). Obecnie role społeczne na nowo stały się narzędziem analitycznym w odpowiedzi na zjawisko wzmożonej aktywności zawodowej kobiet (Hochschild 1997). Dostrzeżono, że konflikt ról jest szczególnie widoczny $\mathrm{w}$ odniesieniu do relacji praca-dom, a badania w tak zwanym obszarze work-life balance (WLB) stały się kluczowe dla nauk społecznych oraz ekonomicznych (np. Milkie, Peltola 1999; Bobrowicz 2007; Gregory, Milner 2009; Pustułka, Ślusarczyk 2016).
Sytuując się w tym ostatnim nurcie konstruktywistycznych i wrażliwych na płeć badań nad WLB, $\mathrm{w}$ artykule definiujemy rolę społeczną za Marshallem jako: konstrukt „uwidaczniający oczekiwania społeczne dotyczące danego statusu czy pozycji społecznej oraz wskazujący wpływ wspomnianych oczekiwań" na jednostkę w danej roli (1998: 570 [tłum. własne]).

Nowoczesna konceptualizacja konfliktów związanych z rolami społecznymi wymaga podkreślenia dwóch charakterystyk tego zjawiska. Po pierwsze, różne sfery życia edukacyjnego, zawodowego i rodzinnego coraz częściej się zazębiają i nie cechują odrębnością, a wyzwania z jednego obszaru wpływają na pozostałe (Gregory, Milner 2009). Przejawami tego zjawiska są nie tylko dobrze opisane konflikty praca-dom, ale też upowszechnienie się sytuacji, gdy aktywność zawodowa oraz edukacyjna odbywają się jednocześnie, a studenci-pracownicy opisują trudności związane z wykonywaniem obu tych ról na satysfakcjonującym ich poziomie. Takie konflikty ról wskazała w badaniach matek-studentek Ruszkiewicz (2012), a na świecie pokazali między innymi Home (1997), Carney-Crompton i Tan (2002), Tones i współpracownicy (2009) czy też Stone i O'Shea (2013).

Z tym ostatnim obszarem, to jest macierzyństwem, wiąże się druga charakterystyka, czyli fakt, że konflikt ról ma charakter upłciowiony. Według badań kobiety doświadczają konfliktów ról w dużo większym stopniu, tak na linii praca-dom, jak i uczelnia-rodzina (por. Hochschild 1997; Home 1997; Bobrowicz 2007; Kotowska, Sztanderska, Wójcicka 2007; Tones i in. 2009; van Rhijn 2014; van Rhijn, Lero 2014; Pustułka, Ślusarczyk 2016). Model podziału obo- 
wiązków domowych jest znacznie bardziej „równościowy" w przypadku partnerów legitymujących się wyższym wykształceniem, niż kiedy partnerzy mają wykształcenie średnie lub zawodowe (Bobrowicz 2007).

Przyczyn upłciowienia zjawiska konfliktu ról upatrywać należy z jednej strony w nietożsamych, historycznie uwarunkowanych oczekiwaniach wobec matek i ojców. Z drugiej natomiast w stereotypowych wyobrażeniach na temat znaczenia pracy zawodowej kobiet, którą to umniejsza się w stosunku do pracy mężczyzn (por. Hochschild 1997; Milkie, Peltola 1999). Zjawiska te są dodatkowo sprzężone. Mianowicie pracujące kobiety są za macierzyństwo „karane” (motherhood penalty), co oznacza: statystycznie wyższe bezrobocie, niższe zarobki i emerytury oraz spowolnienie ścieżek awansu wśród matek. Natomiast mężczyźni są za rodzicielstwo nagradzani (fatherhood premium [por. Haponiuk 2014]), czyli otrzymują uznanie społeczne jako pokłosie roli ojcowskiej.

Istotnym elementem wpływającym na pojawienie się konfliktu ról jest ich realizacja $\mathrm{w}$ ramach tak zwanych chciwych instytucji (Coser 1974; Hochschild 1997). Oznacza to, że nie mogą być one delegowane, gdyż dotyczą wrażliwych sfer życia i są ściśle powiązane z ogólną satysfakcją życiową oraz zaangażowaniem emocjonalnym. Tym samym obowiązki wynikające z ról rodzinnych: bycia matka/ ojcem lub też małżonkiem/-ą, partnerem/-ką, jak i te przynależne statusowi społeczno-ekonomicznemu jednostki jako pracownika w dużej mierze są realizowane osobiście (Milkie, Peltola 1999: 477). Jak pokazały badania Home (1997) nad rodzicami-studentami, ta ostatnia rola jest również realizowana w ramach chciwej instytucji, czyli uniwersytetu (por. Currie, Harris, Thiele 2000) i wymaga - przynajmniej w założeniu - pełnej dyspozycyjności.

Artykuł proponuje empiryczną weryfikację zjawiska doświadczania konfliktów ról przez osoby jednocześnie pracujące, studiujące i wychowujące dzieci we współczesnej Polsce.

\section{Stan wiedzy: uwikłania młodych w matrix ,edukacja-praca-dom"}

Etap życia, jakim jest wchodzenie w dorosłość, jest szczególną soczewką konfliktów i napięć zachodzących podczas podejmowania różnych ról społecznych. Częściowo odpowiada za to zmiana aspiracji młodych ludzi, którzy tak samo jak ich rodzice cenią udane życie rodzinne, ale znacznie bardziej niż starsze pokolenia pragną interesującej pracy i dobrego wykształcenia (Orczykowska 2012; Inglot-Brzęk 2012; Szafraniec 2012; Wrzesień 2016). Krótko mówiąc, w każdej z trzech ról społecznych - rodzica, studenta i pracownika - współcześni 20- i 30-latkowie chcą się spełniać w jak największym stopniu. Młodzi ludzie mierzą się dzisiaj z własnymi wątpliwościami co do wyboru drogi zawodowej i życiowej: mają bowiem zbyt wiele bodźców oraz zbyt duże spektrum możliwości i brak instrumentów wyboru (por. np. Wrzesień 2016). Na to nakłada się doświadczanie ciągłych przemian na polu edukacyjnym, na przykład w programach kształcenia (por. Sadura 2018) czy na rynku pracy, między innymi związane z jego uelastycznieniem (por. Furlong 1992; Kotowska 2007; Haponiuk 2014). Kolejne wydarzenia związane z podejmowaniem „dorosłych" ról społecznych przestają następować 
w niegdyś zakładanym chronologicznym porządku (por. Fenton, Dermott 2006).

Czynniki ekonomiczne związane z niepewnością zatrudnienia (Fenton, Dermott 2006; Settersten 2007; Arnett 2014) - szczególnie kobiet (Kotowska 2007; Haponiuk 2014; Slany, Warat, Krzaklewska 2016) współwystępują ze zmianą społeczną w zakresie obyczajowości małżeńsko-rodzinnej (Slany 2013) oraz stale wydłużającym się okresem „stającej się" dorosłości (emerging adulthood [Liberska 2007; Arnett 2014]). Wiąże się to ze zwiększonymi aspiracjami edukacyjnymi, ale także odraczaniem zawarcia małżeństwa i decyzji o posiadaniu potomstwa. Statystyczny pan młody w Polsce ma 29 lat, panna młoda 27 lat (GUS 2016), a zakładanie rodziny pokrywa się $\mathrm{w}$ czasie $\mathrm{z}$ wyprowadzką z domu rodzinnego. Również decyzja o posiadaniu potomstwa opóźniła się w ostatnich dwóch dekadach o 3 lata. Przeciętny wiek kobiety rodzącej pierwsze dziecko, tak zwanej pierworódki, wynosi 27 lat (GUS 2016).

Tym samym widzimy swoistą rush hour - godzinę szczytu we wszystkich obszarach biograficznych, kiedy to ważne wydarzenia zawodowe, zakończenie edukacji oraz założenie rodziny, dzieją się - w sensie demograficzno-społecznym - w dużym stopniu równocześnie. To powoduje, że wcześniej role społeczne realizowane w sposób linearny obecnie występują razem i tym samym powodują konflikt.

\section{Pogoń za dyplomem: edukacja na poziomie wyższym we współczesnej Polsce}

Poziom wykształcenia Polaków stale rośnie, a $\mathrm{w}$ okresie potransformacyjnym, to jest po prze- mianach 1989 roku, zmiany demograficzne, społeczne i rynkowe zaowocowały nowym krajobrazem szkolnictwa wyższego. Według najnowszych danych (GUS 2019) liczba studentów uczelni wyższych jest ponad trzykrotnie większa (1230 tys. studentów w 2018/2019) niż bezpośrednio po zmianie ustroju (390 tys. studentów w roku akademickim 1990/1991). Doprowadziło to do niemal trzykrotnego wzrostu ogólnej liczby Polaków z dyplomem uczelni wyższej w grupie wiekowej 25-34 lata z nieco ponad 17\% w 2002 roku do 44\% w 2017 roku (Eurostat 2018a).

W literaturze przedmiotu dotyczącej kształcenia na poziomie uniwersyteckim $\mathrm{w}$ Polsce często eksploatowany jest temat instytucjonalnych aktorów społecznych, monitoringu absolwentów oraz procesu przechodzenia z edukacji na rynek pracy (por. Orczykowska 2016; Sarnowska i in. 2016; Szulc 2016). Jednocześnie mniej uwagi poświęca się niestandardowym i nietradycyjnym drogom edukacyjnym w strukturach szkolnictwa wyższego.

Zarówno w Polsce, jak i globalnie populacja tak zwanych studentów nietradycyjnych stale rośnie (por. Carney-Crompton, Tan 2002; Ricco, Sabet, Clough 2009; Tones i in. 2009; Stone, O'Shea 2013), chociaż sama definicja atypowego studenta nie jest jednoznaczna (Chung, Turnbull, Chur-Hansen 2014). Najczęściej portret studenta nietradycyjnego kreowany jest jako negatyw standardowej ścieżki edukacyjnej. Oznacza to wzięcie pod uwage zmiennej wieku student nietradycyjny ma więcej niż 24 lata; statusu zawodowego - praca w pełnym wymiarze godzin; a także sytuacji rodzinnej-studenci i studentki nietradycyjne zwykle mają pod opieką osoby od siebie 
zależne, najczęściej dzieci (Carney-Crompton, Tan 2002; Chung i in. 2014).

W Polsce na szczególną uwagę zasługuje aspekt trybu studiów: o ile studenci studiów stacjonarnych to przede wszystkim osoby młode, wśród których odsetek osób powyżej 25. roku życia waha się w granicach 3-5\%, to wiek studentów niestacjonarnych jest zasadniczo wyższy. Raport GUS Kształcenie dorostych 2011 (2013) pokazuje, że powrót do formalnej edukacji (niezależnie od jej poziomu) w późniejszym wieku (25-64 lata) częściej podejmują kobiety (55\%) oraz mieszkańcy miast (77\%). Studenci powyżej 25. roku życia wybierają przede wszystkim studia na kierunkach społecznych, ekonomicznych i prawnych, zarówno aby uzyskać dyplom uniwersytecki (52\%), jak i po to, by zrealizować studia podyplomowe $(24 \%)$.

\section{Z edukacji na rynek pracy}

Od lat w politykach społecznych podnosi się pozytywny wpływ dyplomu uniwersyteckiego na niwelację zagrożenia bezrobociem (Jelonek, Kasparek, Magierowski 2015). Osoby z wyższym wykształceniem pracują częściej (odsetek pracujących z dyplomem to $80 \%$ wobec $44 \%$ dla osób z wykształceniem podstawowym bądź gimnazjalnym) i mają mniejsze problemy ze znalezieniem pracy niezależnie od województwa (Jelonek i in. 2015). Niemniej to przede wszystkim osoby młode muszą się zmierzyć z uelastycznianiem rynku pracy i aż $54 \%$ pracuje na umowach czasowych na nisko opłacanych stanowiskach (Eurostat 2018b).

Jak już wspomniano, spotęgowane poczucie niepewności dotyka kobiety, które znacznie częściej pozostają poza rynkiem pracy mimo znaczniejszych osiągnięć edukacyjnych. Wśród osób z wyższym wykształceniem, szczególnie w newralgicznej kohorcie 25-34-latków, przeważają kobiety. Aż 54\% z nich legitymuje się dyplomem uczelni wyższej wobec 34\% mężczyzn (Eurostat 2018a). Pozycja kobiet z jednej strony związana jest z wydłużającą się trajektorią edukacyjną, z drugiej zaś wynika z podejmowania ról społecznych związanych z zakładaniem rodziny i posiadaniem dzieci (Bobrowicz 2007; Kotowska 2007). Badacze podnoszą, że absolwentki - szczególnie młode matki - są grupą sprekaryzowaną i dyskryminowaną na polskim rynku pracy. Aż 40\% kobiet uważa, że przerwa w karierze związana z urodzeniem dziecka miała negatywny wpływ na ich rozwój zawodowy (Kotowska 2007).

Jednoczesna nauka i praca jest dzisiaj zjawiskiem powszechnym. Około 40\% osób w wieku 15-34 lata, które uczyły się, jednocześnie też pracowały. Co piąta z tych osób podejmowała zajęcia nieodpłatne (GUS 2017). Chociaż Główny Urząd Statystyczny nie monitoruje szczegółowo aktywności zawodowej uczniów i studentów, dane wskazują (GUS 2011; 2017; Eurofund 2014), że najczęściej zjawisko to dotyczy osób kształcących się w trybie tak zwanym niestacjonarnym, czyli zaocznym oraz wieczorowym (odpowiednio ok. 66\% i 40\% osób pracujących zawodowo i uczących się jednocześnie).

Popularność podejmowania odpłatnych zajęć wzrasta wraz z poziomem wykształcenia. Studenci posiadający już dyplom licencjata lub inżyniera podejmują pracę $\mathrm{w}$ trakcie procesu kształcenia nawet czterokrotnie częściej niż osoby na niższych poziomach edukacji. Jeszcze w 2009 roku takich osób 
było około 40\% (Eurofound 2014). Bardziej aktualne dane (GUS 2017) mówią nawet o 60\% pracujących studentach $\mathrm{z}$ dyplomem studiów I stopnia ${ }^{2}$. Analizy te pokrywają się z badaniem Bilansu Kapitału Ludzkiego z 2013 roku, w którym zapytano studentów o doświadczenia pracy w przeciągu ostatniego roku. Wówczas $40 \%$ badanych wskazało, że takie doświadczenia posiada. Najczęściej pracę w trakcie studiów podejmowali studenci kierunków związanych z usługami dla ludności (51\%) oraz dziennikarstwem i informacją (49\%). Najrzadziej zatrudnienie i edukację łączyli studenci opieki społecznej (25\%), kierunków biologicznych (34\%), matematycznych i statystycznych (34\%) oraz medycznych (34\%). Pracująco-studiujący najczęściej (52\%) wykonywali prace powiązane $\mathrm{z}$ handlem i usługami (Jelonek, Antosz, Balcerzak-Raczyńska 2014: 40). Dla polskiego studenta podjęcie pracy wiąże się ze znacznym obciążeniem czasowym, a co za tym idzie - rodzi większe napięcia między rolami studenta i pracownika. Studenci pracujący w Polsce są „atypowi”, realizując zazwyczaj model pełnoetatowej pracy i niepełnoetatowej edukacji (por. Eurofund 2014).

Przechodząc do absolwentów Uniwersytetu SWPS, którzy stanowią grupę respondentów w prezentowanym badaniu, to wiadomo, że około $66 \%$ z nich zdobywa doświadczenie zawodowe już w trakcie studiów (Grabowska-Lusińska 2012), więc można powiedzieć, że na różne sposoby łączą pracę i edukację. Dość silną motywacją do łączenia edukacji i pracy jest próba usamodzielniania się od rodziców

${ }^{2}$ W późniejszych analizach GUS (2017) wspomina, że wśród osób z wyższym wykształceniem, nawet $66 \%$. mogło łączyć edukację z pracą. Prawdopodobnie jednak chodzi tutaj zarówno o pracę niepłatną, jak i odpłatną. poprzez posiadanie własnych pieniędzy. Młodym osobom przed 30. rokiem życia towarzyszy także poczucie powinności pracy, by jak najwcześniej gromadzić niezbędne zawodowe doświadczenie i budować przewagę konkurencyjną na rynku pracy (por. Sarnowska i in. 2016; Sarnowska, Winogrodzka, Pustułka 2018).

\section{Matki i ojcowie studenci w świetle badań}

W Polsce dostrzega się brak szeroko zakrojonych badań na temat liczby studentów-rodziców. Temat ten do tej pory nie był też częścią monitoringu absolwentów na Uniwersytecie SWPS (por. Grabowska-Lusińska 2012). Szerzej o skali zjawiska możemy wnioskować między innymi z olbrzymiego zainteresowania zakończonym już rządowym programem „Maluch na uczelni", w ramach którego w 2015 roku 43 publiczne i niepubliczne uczelnie w całej Polsce otrzymały fundusze ministerialne na tworzenie nowej i dofinansowanie istniejącej sieci opieki żłobkowej (łącznie program objąć miał 2,7 tys. miejsc). Programowi towarzyszyły kampanie informacyjne, które miały normalizować zjawisko rodzicielstwa w trakcie studiów oraz sprzyjać empatii wobec osób z dziećmi na uczelniach. Do pozostałych celów kampanii należało informowanie studentek i studentów o przysługujących im świadczeniach, takich jak urlop dziekański, indywidualny tok nauki, a także comiesięczne finansowe świadczenia rodzicielskie.

Badania naukowe poświęcone studentom-rodzicom mają w Polsce raczej charakter incydentalny. Jednym z projektów poświęconych łączeniu pracy, edukacji i obowiązków rodzinnych był projekt 
„Aktywność zawodowa i edukacyjna a obowiązki rodzinne" kierowany przez Irenę E. Kotowską (2007). Przeprowadzone $\mathrm{w}$ ramach projektu analizy potwierdziły hipotezę, że wraz z pojawieniem się dzieci w gospodarstwie domowym aktywność edukacyjna się zmniejsza. Trzeba pamiętać, że część osób młodych w dalszym ciągu będzie wybierać realizację drogi do dorosłości według tradycyjnego schematu - najpierw edukacja, potem rodzina. Niemniej wyzwania w łączeniu obu tych sfer będą się wiązać z dwoma czynnikami. Po pierwsze, koszty związane z posiadaniem dziecka (te faktyczne i te utracone) ograniczają możliwość podejmowania płatnej edukacji. Po drugie, opieka nad dzieckiem jest czasochłonna i wymaga alokacji czasu wolnego na zajmowanie się obowiązkami domowymi (Litwiński 2007).

Bojarska (2017) opisała z perspektywy pedagogicznej wyniki ankiet i wywiadów z dwudziestoma matkami-katoliczkami studiującymi w Lublinie. Znaczący był fakt, iż jej respondentki studiowały dziennie i nie pracowały oraz były mężatkami, awyzwania związane z łączeniem wyłącznie dwóch ról matek i studentek napotykały stosunkowo rzadko. Badaczka wskazała na małżonków oraz inne kobiety - matki, teściowe, koleżanki - jako najważniejsze osoby wspierające matki-studentki (Bojarska 2017).

Ruszkiewicz (2012) przeprowadziła badanie na nieco mniejszą skalę wśród dziewięciu matek studiujących pedagogikę. Badaczka - dzięki zastosowanej metodzie studiów przypadków - uchwyciła różnice między kobietami w różnych typach związków (m.in. kohabitujących) oraz tymi matkującymi samodzielnie. Autorka wskazała, że, niezależnie od kształtu relacji dorosłych, rola matki staje się dominująca (prymarność roli rodzica) i prowadzi do deprecjonowania wagi wyników uzyskiwanych na studiach: najważniejsze staje się „zaliczenie” przedmiotu, a mniej ważne pobudki intelektualno-ambicjonalne kształcenia. Mimo postrzeganej przychylności wykładowców, studentki-matki nie brały udziału w życiu studenckim, a największymi wyzwaniami było dla nich zapewnienie stałej opieki dla dzieci oraz organizacja czasu w życiu codziennym (Ruszkiewicz 2012).

Dla rozważań o łączeniu różnych ról istotne mogą być trendy obserwowane $\mathrm{w}$ ramach zachodnich systemów kształcenia uniwersyteckiego, gdzie od lat maleje odsetek tak zwanych studentów tradycyjnych, czyli rozpoczynających studia od razu po szkole średniej. Najbardziej dynamiczny wzrost obserwuje się szczególnie $\mathrm{w}$ grupie nietradycyjnych studentek - kobiet po 25. czy nawet po 35. roku życia (np. Home 1997; Carney-Crompton, Tan 2002; Ricco i in. 2009; Tones i in. 2009; Stone, O'Shea 2013). Wśród studentek z tej grupy podkreśla się związek między trajektoriami edukacyjnymi a rodzicielstwem (m.in. Carney-Crompton, Tan 2002; Stone, O’Shea 2013), zwłaszcza w kontekście predykatów ukończenia edukacji oraz wewnętrznych, samorealizacyjnych motywów kształcenia. Dość często wśród tak zwanych nietradycyjnych studentów odnajdujemy osoby z nieakademickim kapitałem kulturowym, wywodzące się z klas niższych (szczególnie robotniczej) i pochodzące $z$ terenów niezurbanizowanych (por. Sadura 2018).

Kanadyjskie badanie sondażowe ( $\mathrm{n=398)}$ studentów-rodziców jako subpopulacji uczących się dorosłych 
wskazało na wpływ poczucia własnej skuteczności (self-efficacy) czy sprawstwa na zadowolenie z uniwersytetu, z życia rodzinnego oraz z życia w ogóle. Poczucie własnej skuteczności rosło wraz z jednostkową oceną umiejętnością radzenia sobie z różnymi rolami, na przykład utrzymywanie równowagi uniwersytet-dom, choć znaczne różnice występowały w odniesieniu do zmiennych socjodemograficznych, takich jak: wiek dzieci, typ związku oraz tryb studiowania (van Rhijn, Lero 2014). Analizy van Rhijn (2014) wskazały też, że aż dla 40\% respondentów nieukończenie studiów wynikało bezpośrednio z powodów rodzinnych.

W świetle badań jakościowych podniesiono, że $\mathrm{W}$ porównaniu $\mathrm{z}$ „tradycyjnymi” studentami, osoby podejmujące formalną edukację w późniejszym wieku muszą brać pod uwagę swoją atypową sytuację mieszkaniową. Zazwyczaj nie mieszkają już w domu rodzinnym, a raczej prowadzą własne gospodarstwo domowe, wspólnie z partnerem i zależnymi od siebie dziećmi (Scott i in. 1996). W grupie tak zwanych mature students zaobserwowano liczne bariery przekładające się na atrycję, czyli znacznie niższe niż dla ogólnej populacji odsetki osób kończących studia w ramach danego rocznika. Wskazano głównie na obwarowania finansowe, między innymi brak środków na sfinansowanie czesnego. Wśród innych przyczyn wymieniano problemy $\mathrm{z}$ zapewnieniem opieki dla dzieci w czasie nauki oraz trudności w zaadaptowaniu się do zdominowanego przez młodszych absolwentów środowiska studenckiego (Tones i in. 2009).

W badaniach Scott i współpracowników (1996) uwypuklono z kolei kluczową rolę klasy spo- łecznej, gdyż kobiety z niższym statusem często opuszczały uniwersytet z uwagi na brak wsparcia rodzinnego, zbyt wysokie koszty, a także olbrzymi ciężar związany z prowadzeniem domu. Równie ważna okazała się rola wieku. Młodsze matki rezygnowały z edukacji ze względów rodzinnych - szczególnie brak możliwości zorganizowania opieki dla dzieci. Natomiast starszymi matkami kierowało niezadowolenie ze studiów oraz wyzwania związane z niedostatkami kapitału kulturowego. Te ostatnie przekładały się na trudności praktyczne związane z brakiem kompetencji do studiowania.

Jakościowe badania $(\mathrm{n}=37)$ przeprowadzone przez Stone oraz O'Shea (2013) pokazały dualizm czynników wpływających na sytuację kobiet o nietradycyjnym przebiegu karier edukacyjnych. $Z$ jednej strony wskazano na czynniki obiektywne, takie jak: brak czasu oraz niewystarczające zasoby finansowe, z drugiej zaś - odkryto bardziej subtelny wpływ poczucia winy i modelu samopoświęcania się kobiet, wskazując na wysoki stopień upłciowienia doświadczeń rodziców na uczelniach wyższych.

Podsumowując, badania międzynarodowe pokazują, że z jednej strony bycie rodzicem mobilizuje do podjęcia edukacji (Home 1997; Carney-Crompton, Tan 2002; Ricco i in. 2009; Tones i in. 2009; Stone, O'Shea 2013), ale jednocześnie studentki- i studenci-rodzice są zdecydowanie bardziej narażeni na rezygnację z rozpoczętej edukacji na poziomie wyższym (van Rhijn 2014; van Rhijn, Lero 2014) oraz częściej doświadczają tak zwanych napięć i konfliktów ról, które wynikają ze sprzecznych oraz licznych zadań przypisywanych społecznie rolom rodzicielskim, 
studenckim oraz zawodowym (Home 1997; Currie i in. 2000).

\section{Metodologia badania}

Omawiane badanie zostało zrealizowane na przełomie 2017 i 2018 roku w ramach projektu Wyzwania i strategie łączenia edukacji z rodzicielstwem wśród studentów i absolwentów Wydziału Nauk Humanistycznych i Społecznych Uniwersytetu SWPS (EduPRo) i miało charakter eksploracyjny. Jest ono kontynuacją badania przeprowadzonego na przełomie 2015 i 2016 roku pod tytułem Losy zawodowe absolwentów Wydziału Nauk Humanistycznych i Społecznych Uniwersytetu SWPS: wartość dyplomu i łączenie edukacji z praca, w którym pogłębiono temat łączenia edukacji z życiem zawodowym (Sarnowska i in. 2016). Głównym celem tego projektu było zbadanie, jak studentki i studenci na WNHiS Uniwersytetu SWPS łączą studia wyższe z pracą i życiem rodzinnym. W badaniu szczególną uwage przywiązano do zależności między rolami społecznymi podejmowanymi przez młodych w kontekście zakładanego konfliktu ról, związanego z przywoływaną wcześniej rush hour godziną szczytu związaną z jednoczesną realizacją przez badanych ról społecznych w ramach "chciwych" instytucji.

Zastosowane zostało podejście jakościowe, które pozwoliło na zdobycie szczegółowej wiedzy w wyżej wskazanym temacie. Techniką badawczą był indywidualny wywiad pogłębiony częściowo ustrukturyzowany przeprowadzony wśród 30 osób (studentek/studentów oraz absolwentek/absolwentów) o zróżnicowanych cechach socjodemograficznych. Dobór próby miał charakter celowy i dogodnościo- wy; od razu założono większą reprezentację matek $(K=26, M=4)$. Kryterium warunkującym udział w badaniach było posiadanie co najmniej jednego dziecka w wieku 0-15 lat oraz wiek 19-35 lat w okresie studiowania. Osoby badane pochodziły z różnych miast, miały zróżnicowaną sytuację rodzinną oraz były studentkami/studentami wszystkich 3 stopni studiów: licencjackich, magisterskich oraz doktoranckich.

Scenariusz wywiadu został skonstruowany tak, by wpierw uchwycić każdą z ról osobno (studenta, pracownika, rodzica), a następnie sprawdzić, czy i ewentualnie w jakim zakresie badana/badany odczuwa konflikt ról, między innymi poprzez nakładanie się obowiązków i konieczności priorytetyzowania różnych sfer, a także czy postrzega trzy instytucje jako „chciwe”. Wywiady trwały ok. 40-50minut i pozwalały osobom badanym na zagłębienie się $\mathrm{w}$ temat.

W opracowaniu materiału wykorzystano siatki analityczne ( $z w$. gridy [Neale i in. 2015]). Były to przygotowane na etapie opracowania narzędzi badawczych tabelaryczne formy rejestracji odpowiedzi respondentów, dołączone do przewodnika wywiadu oraz uzupełniane przez zespół badawczy w trakcie i zaraz po wywiadzie. Narzędzie to umożliwia wielowymiarową analizę tematów oraz przypadków. Dzięki takiemu podejściu można porównywać doświadczenia związane z edukacją, pracą i rodzicielstwem pomiędzy badanymi osobami. Ułatwia to także skrzyżowanie ze sobą zmiennych wyrażonych pogłębionym opisem i wychwycenie wpływu różnych czynników na godzenie roli studenta, pracownika oraz rodzica. 
Tabela 1. Obszary analityczne i kody tematyczne.

\begin{tabular}{l|l}
\hline Obszary tematyczne & Lista kodów \\
\hline $\begin{array}{l}\text { Studiowanie } \\
\text { kierunek, poziom studiów, motywy wyboru kierunku, motywy wyboru uczelni, ocena } \\
\text { kierunku, ocena uczelni, wyobrażenia o studiowaniu, znaczenie dyplomu na rynku } \\
\text { pracy, wpływ dyplomu na drogę zawodową }\end{array}$ \\
\hline obecny status na rynku pracy, pierwsza praca, znaczenie pierwszej pracy, praca a kieru- \\
\hline nek studiów, najważniejsza praca, plany zawodowe, wpływ studiowania na jakość pracy
\end{tabular}

Źródto: opracowanie własne.

Na potrzeby analizy dokonano otwartego, tematycznego opracowania materiału, posługując się odpowiednimi kodami dla poszczególnych obszarów (por. tabela 1). Kody wykorzystane na potrzeby artykułu to: wpływ dyplomu na drogę zawodową, praca a kierunek studiów, plany zawodowe, wpływ studiowania na jakość pracy, decyzje o posiadaniu dzieci, podział obowiązków, wpływ życia rodzinnego na pracę, role życiowe, decyzje o łączeniu ról, organizacja czasu, wsparcie rodziny/ brak wsparcia rodziny dla łączenia ról, rola pracodawcy w łączeniu ról, wsparcie/ brak wsparcia instytucjonalnego, czas wolny, ocena łączenia trzech ról.

\section{Młodzi w potrzasku "chciwych instytucji” - wyniki badania jakościowego}

Uczestnicy badania doświadczyli lub wciąż doświadczają swoistej rush hour - biograficznej godzi- ny szczytu. Przykładowo, Marianna w ciągu zaledwie trzech lat wyszła ponownie za mąż, urodziła dwójkę dzieci, diametralnie zmieniła ścieżkę kariery oraz rozpoczęła pracę nad doktoratem. Podobnie Ela, która z dwójką małych dzieci przeprowadziła się do innego miasta, podjęła pracę i zaczęła studia magisterskie w przeciągu roku. W biografii Zuzanny zauważamy, że rozpoczęcie studiów i bycie matką dwójki dzieci skłoniło ją do wyjścia z nieudanego związku. Taka sytuacja życiowa badanych, które pracują, wychowują dzieci i zdobywają wykształcenie, może przyczyniać się do odczuwanych i artykułowanych przez nie konfliktów ról, które staramy się zaprezentować w analizie. Badani wyraźnie wskazywali, że ich sytuacja jest trudna i rodzi konflikty pomiędzy różnymi rolami.

Doświadczanie konfliktu ról wydaje się być powszechne i niezależne od płci. W odniesieniu do 
hierarchizacji ról przez samych badanych, w triadzie: rodzic, student i pracownik, pierwsza z ról wiedzie prym i jest centralna dla większości wyzwań, przed którymi stawali lub nadal stają badani. Jednocześnie dostrzegali oni również problemy na linii edukacja-praca, co wydaje się być spójne z wynikami wcześniejszych badań (Scott i in.1996; Tones i in. 2009; Stone, O'Shea 2013). Łączenie tych dwóch ról może wywołać poczucie straconego czasu, jak w przypadku Ani, która pracowała w korporacji i przez pierwsze dwa lata studiów doktoranckich nie miała czasu na pracę naukową. $Z$ podobnego powodu Małgosia podjęła decyzję o porzuceniu pracy na rzecz „,chciwego uniwersytetu” (por. Home 1997; Currie i in. 2000):

Na przełomie licencjata i magistra podjęłam pracę. $\mathrm{Na}$ początku studiów na Uniwersytecie SWPS pracowałam. Zrezygnowałam koło grudnia [I roku studiów drugiego stopnia - przyp. aut.], bo pracodawca nie chciał dawać mi co drugiego weekendu wolnego. [...] Byłam skrajnie przemęczona. Byłam nawet zadowolona, że musiałam w końcu odejść. [Małgosia, jedno dziecko]

W przypadku typowych sekwencji biograficznych edukacja-praca-rodzina łatwo jest ustalić prymarną rolę społeczną respondenta. Przykładowo, badając standardowe ścieżki, Sarnowska i Grabowska (2018) pokazały, że osoby studiujące dziennie trywializowały swoje role pracownicze $\mathrm{w}$ trakcie nauki, przede wszystkim widząc się $\mathrm{w}$ roli studenta. Niwelowały zatem konflikt ról przez umiejscowienie jednej z aktywności na mniejszym poziomie istotności. W naszym badaniu, o ile rola rodzicielska jest prymarna, to dodatkowy, nasilony kon- flikt ról wynika z biograficznej rush hour, kiedy to respondentom trudno określić, czy ważniejsza jest praca, czy może studiowanie. W tej sytuacji decydują często czynniki ekonomiczne. Studenci-rodzice z lepszą sytuacją materialną pracę ograniczają lub z niej rezygnuja, ograniczając skonfliktowane role społeczne do dwóch.

Na doświadczenie konfliktu ról może się nałożyć również nieprzystawalność studiów i pracy zawodowej pod względem statusu społecznego. Praca daje stabilność finansową, ale ponieważ jest znacząco poniżej możliwości, jej wykonywanie budzi pewien opór. Mówi o tym Teresa.

Wolałabym nie pracować w biurze, ale nie mam wyjścia, musiałam zarabiać. Dla zdrowia psychicznego jest dobrze mieć pracę. Ale są to dwie wykluczające się role - doktorat i status znacznie niższy w pracy. [Teresa, jedno dziecko]

Jest to o tyle ciekawe, że przytoczone wcześniej dane Eurostatu (2018b) o zatrudnieniu oraz badanie dotyczące sektorów rynku pracy prowadzone przez Jelonek i współpracowników (2014) wskazują, że często praca studentów to właśnie praca poniżej kwalifikacji. Oznaczałoby to też, że dotyczy to nie tylko studiów I i II stopnia, ale również doktoranckich. Jednocześnie wydaje się, że jest ona jedynie środkiem do celu (edukacyjnego czy finansowego), co może łagodzić poczucie konfliktu ról i oczekiwań społecznych stawianych pracownikom i studentom.

Jacek i Damian wskazywali z kolei, że pozytywne podejście pracodawcy do ich nauki sprawiało, że mieli czas na obie role, choć w pewnej mierze 
oznaczało to rezygnowanie $\mathrm{z}$ zawodowych zobowiązań. Można przypuszczać, że pracodawca może oczekiwać przyszłych zysków z wyższego wykształcenia pracownika, więc na ten moment obniża oczekiwania stawiane mu na co dzień. Jedna „chciwa” instytucja ustępuje drugiej w nadziei na zwrot z inwestycji.

Co istotne, badani również dostrzegają, że łączenie roli studentki/studenta $\mathrm{z}$ pracownicą/pracownikiem, przynajmniej na jakiś czas, zatrzymuje ich rozwój zawodowy. Wypowiedź Mariki: „Prawdopodobnie byłabym już $\mathrm{w}$ innej firmie. Ze względów praktycznych nie szukam innego miejsca pracy” [Marika, dwoje dzieci] oraz Teresy: „Praca nad doktoratem mnie zablokowała. Gdybym nie zdecydowała się na ten ruch, to moja sytuacja mogłaby zupełnie inaczej wyglądać" dobrze obrazują to zjawisko. Niemniej ich motywacja zdaje się być zbliżona do motywacji pracodawców i studia są inwestycją w przyszły rozwój zawodowy. Same więc decydują, ile swojego czasu i uwagi dają "chciwym" instytucjom, więc łatwiej im ten konflikt ról złagodzić.

Jednocześnie rodzice, którzy nie mogą sobie pozwolić na rezygnację z zarobkowania, znajdują się bliżej wcześniejszych ustaleń badaczy (Scott i in. 1996; Tones i in. 2009; Ruszkiewicz 2012) i spychają rolę studencką na dalszy plan, często porzucając motywacje samorealizacyjne. Traktują wówczas studiowanie jako część drogi zawodowej i aktywnie sprzeciwiają się "chciwości" uniwersytetu, przyjmując mentalność „żeby zdać” i chcąc jak najszybciej z roli studenckiej wyjść. Mówi o tym Sylwia:
Podczas pierwszej pracy nie studiowałam. Teraz mam zdecydowanie mniej czasu. Pracuję z domu, robię wszystko szybko, mniej się przykładam. Borykam się z natłokiem obowiązków: do pracy, na uczelnię. [Sylwia, dwoje dzieci]

Łączący edukację z pracą i rodzicielstwem respondenci i respondentki w naszym badaniu zdobywali dyplomy $\mathrm{w}$ trybie przede wszystkim niestacjonarnym. Nawet w przypadku doktorantów/-ek uczęszczali na zajęcia w weekendy. Doświadczali więc pewnego paradoksu: $\mathrm{z}$ jednej strony oczekiwania społeczne sugerowały, że skoro nauka jest aktywnością sobotnio-niedzielną, to studentki/-ci podejmować powinni pracę $\mathrm{w}$ tygodniu. $\mathrm{Z}$ drugiej strony oznaczało to $\mathrm{w}$ praktyce, że student-pracownik nie ma ani jednego dnia przerwy od pracy/nauki przez długie tygodnie.

\section{Matka Polka i Polak pracujacy}

W powyższych przykładach różne są relacje dotyczące konfliktu w zależności od płci. Wydaje się, że kobiety i mężczyźni postrzegają go inaczej. Dla kobiet jest to stałe bycie rodzicem i organizatorem życia rodzinnego niezależnie od tego, gdzie aktualnie przebywają. Opowiadała o tym Ewa, która zarządzała życiem rodzinnym ",na zapas”, między innymi przygotowując posiłki na czas nieobecności w domu. Tego zadania nie delegowała nikomu z rodziny, ani nie polegała na wyspecjalizowanej instytucji (por. Milkie, Peltola 1999), co potwierdza postrzeganie rodziny jako „chciwej” instytucji. Podobnie było w przypadku Mariki, która z pewnym żalem wręcz stwierdza, że przygotowywała plan na weekend podczas jej nieobecności, a mąż spijał śmietankę. 
Z kolei Marianna cokolwiek by robiła, cały czas borykała się z poczuciem, że nigdzie nie jest odpowiednio zaangażowana, a obowiązki wynikające z posiadania dzieci stawiała i tak na pierwszym miejscu kosztem innych zobowiązań czy też potrzeb (por. Stone, O'Shea 2013; Bojarska 2017).

Łączę wszystkie trzy role [matki, pracownika, studenta - przyp. aut.] i nie ma dobrego modelu - jedno i drugie jest trudne. Praca z dzieckiem na kolanach nie jest dobra. Jesteś cały dzień poza domem - nie widujesz dziecka w ogóle. Najtrudniejsze jest wyłączenie wyrzutów sumienia... i żeby mieć z tyłu głowy dzieci i partnera, który wspiera. [Marianna, dwoje dzieci]

W odpowiedziach badanych kobiet brak czasu i zmęczenie wiązało się głównie z łączeniem centralnej roli rodzica (por. Ruszkiewicz 2012) ze wszystkimi pozostałymi rolami, które krążyły wokół macierzyństwa jak satelity. Jest to niemal namacalny dowód tego, jak ta swoista rush hour była dla kobiet wyczerpująca i pomimo radzenia sobie z trudnościami negatywnie wpływała na ogólne poczucie satysfakcji z życia (por. Scotti in.1996; Gregory, Milner 2009; Tones i in. 2009; Stone, O'Shea 2013; Bojarska 2017). Respondentki cały czas starały się wszystko pogodzić i podejmować decyzje o „niegotowaniu, niesprzątaniu czy niepraniu”, robiąc, co mogły, aby „zapewnić taką samą ilość czasu, żeby nikt nie czuł się pokrzywdzony i żeby nie zwariować i pospać" [Ewa, dwoje dzieci]. Podobnie określiła to Marianna:

Jestem mamą - najważniejsza dla mnie rola. Mam poczucie misji i upływającego czasu, nadrabiania nieobecności (...) [dzieci, przyp. autor] dorastają, jest coraz trudniej - to pochłania czas, emocje. [Marianna, dwoje dzieci]

Z wypowiedzi badanych wynikają nie tylko komponenty związane z czasem i alokacją go na obowiązki rodzinne (Litwiński 2007), ale też czynniki związane z emocjami i poczuciem niespełnienia. Można powiedzieć, że dotychczas opisywany dla roli pracownika fenomen motherhood penalty występuje także w kontekście studiowania, gdzie kobiety czują się w rolach akademickich mniej adekwatnie i mają mniejsze pole do samorealizacji. Rola rodzinna jest niejako priorytetową soczewką, przez którą postrzegane są (i same się postrzegają) badane - studiujące i pracujące matki (por. Kotowska 2007).

Tym samym narracje studentek USWPS potwierdzają, że kobiety mają słabsze poczucie własnej skuteczności (self-efficacy) i krytycznie odnoszą się do tego, jak radzą sobie z rolami (por. van Rhijn, Lero 2014). Można podejrzewać, że jest to związane z tym, jak konstruują oczekiwania społeczne wobec pełnionych przez siebie ról. $Z$ racji tego, że we własnych oczach nie spełniają tych oczekiwań, a także z uwagi na fakt, że obiektywnie łączenie tych trzech obszarów jest dużym wyzwaniem, może to rodzić wewnętrzne konflikty.

[Łączenie tych trzech ról - przyp. aut.] to duży stres. Największym wyzwaniem jest, żeby to nie odbiło się na dzieciach i relacji z nimi. [Sylwia, dwoje dzieci]

Brak czasu. Pogodziłam się brakiem czasu dla siebie, ale brak czasu na wszystko. (...) Czasu dla dzieci jest zawsze za mało. Czasu na pisanie doktoratu również. [Marika, dwoje dzieci] 
Dla porównania w relacjach mężczyzn nie pojawiały się wyrzuty sumienia, a bardziej zobowiązania i umowy z partnerkami. Pytani o role, mówili:

Ja nie miałem wyjścia - pracować musisz, bo musisz utrzymać rodzinę. Studiować chcesz, bo chcesz tę rodzinę utrzymywać za jakiś czas lepiej. Łańcuch przyczynowo-skutkowy. [Damian, dwoje dzieci]

Wychowanie dzieci [najważniejszy projekt w życiu człowieka] - ojciec, poświęcanie czasu. Głowa rodziny, osoba, która utrzymuje rodzinę. Najpierw rodzina, później praca. [Jacek, dwoje dzieci]

Dla Damiana podjęcie studiów było naturalnym krokiem związanym z przyszłością rodziny, więc przyjął, że role trzeba pogodzić. Zwrócił też uwagę, że jego postrzeganie może być inne od tego, jak kobiety podchodzą do łączenia ról.

Jak kobieta mówi o swoich rolach, to jest to porozkładane na małe atomy. Jak facet mówi, partner - to jest w tym wszystko. Nie patrzę na siebie w kategoriach roli. Jak powiem o sobie rodzic, to jestem rodzic kompletny: wypiorę, ugotuję, odprowadzę, nauczę, przytulę, poprawię i tym podobne. Jako rodzic to kompletnie nie ma „podroli”, której nie robię. Mogę coś robić chętniej lub nie, ale robię wszystko. [Damian, dwoje dzieci]

W relacjach badanych mężczyzn nie pojawiały się takie dylematy, o jakich słyszeliśmy w relacjach kobiet, co by potwierdzało wyniki badań światowych (por. Home 1997; van Rhijn 2014; van Rhijn, Lero 2014) w kontekście Polski. Niemniej nie oznacza to, że żaden z mężczyzn nie doświadczał dylematów i konfliktów. Jeden z respondentów - Paweł - wziął na siebie ciężar opieki nad dzieckiem i łączenia tego z pracą zawodową i studiami. Badany wybrał wolny zawód, który umożliwiał elastyczność w podejmowaniu zobowiązań zawodowych. To oznacza, że odczuwał te same konflikty, o których mówiły respondentki. Niezwykle trudno było mu łączyć wszystkie trzy role, co zakończyło się problemami osobistymi i depresją.

Większość obowiązków wziąłem na siebie, bo mogłem sobie na to pozwolić, pracując $\mathrm{w}$ domu. Ale skończyło się to depresją. Jestem najniżej w drabinie pokarmowej mojego syna i jestem wydawcą posiłków. [...] frustrację miałem, jak syn jeszcze nie poszedł do przedszkola, bo studiowałem, zajmowałem się dzieckiem, pracowałem po nocach. Rodzice musieli pomagać. [Paweł, jedno dziecko]

Z relacji Pawła wynika, że problemy są konsekwencją różnych wyborów niekoniecznie dokonanych świadomie przez niego. Sugeruje wręcz, że „[ojcostwo] to najgłówniejsza rola, w którą dał się wpisać". Nie była to dla niego naturalna sytuacja, co można tłumaczyć procesem socjalizacji, w którym wskazuje się na dominantę tak zwanego modelu etyki troski w wychowaniu dziewczynek w Polsce (Titkow 2007). Dla mężczyzn taki wzór wychowania nie obowiązuje. Nie obserwują zatem modelu, gdzie to mężczyzna zajmuje się domem, a kobieta głównie pracuje zawodowo, i konflikt ról, jeśli do niego dochodzi, odczuwają mocniej. Równie interesujące jest to, że Paweł - inaczej niż badane kobiety - nie odczuwał aż tak dużego poczucia porażki, prosząc o wsparcie rodziców i delegując swoje ojcowskie obowiązki. 


\section{Rodzic jako rola wiodaca}

Jak zasygnalizowano wcześniej, respondenci i respondentki wymieniali wiele ról, które pełnili w życiu: rodzica, pracownika/pracowniczki, studenta/studentki, siostry/brata, przyjaciółki/przyjaciela, partnera/partnerki, córki/syna oraz inne, mniej oczywiste, na przykład właściciela/-ki psa. Kolejność wchodzenia w poszczególne z nich oraz ich ważność są nierzadko zróżnicowane, co wskazywałoby na nowe modele tranzycji do dorosłości (por. Sarnowska i in. 2016). Niezależnie jednak od tego, rola rodzica okazywała się być centralna, tak dla podejmowanych decyzji edukacyjno-zawodowych (por. Home 1997; Carney-Crompton, Tan 2002; Kotowska i in. 2007; Ricco i in. 2009; Tones i in. 2009; Stone, O'Shea 2013), jak i dla życia w ogóle. O hierarchii wypełnianych ról badani mówili następująco:

[Najważniejsza jest - przyp. autor] rola mamy pewnie? Mamy, partnerki, koleżanki, pracownika - póki nieletni są nieletni, ale raczej nie myślę o większych zmianach - bo może będą wnuki. [Martyna, dwoje dzieci]

Jestem ojcem-opiekunem codziennym, to ja robię śniadanie, odbieram z przedszkola. Najgłówniejsza rola, w jaką dałem się wpisać. Od 2-3 lat jak studiowałem, to rola studenta też była ważna, bo miałem poczucie rozwoju. Praca nie jest dla mnie jakoś super ważna. [Paweł, jedno dziecko]

Jednocześnie przez fakt, że rola rodzica była wskazywana jako kluczowa (podobnie jak w badaniach Ruszkiewicz [2012]), wokół niej badani odczuwali największy konflikt i to wpływało na ogólnie odczuwaną satysfakcję z życia (Goode 1960; van Rhijn, Lero 2014). Respondenci wymieniali straty i definiowali niemożność/bezradność połączenia tej roli z innymi bez ponoszenia nadmiernych kosztów. Chciwość wszystkich trzech instytucji (Coser 1974; Hochschild 1997; Home 1997) oraz ich oczekiwanie, że żadne obowiązki nie będą delegowane, rodziło wśród badanych liczne konflikty:

Nie da się na 100 procent. Dzieci zawsze tracą na tym, że matki nie ma przez trzy lata co drugi weekend, związek cierpi, plus po zjeździe [na uczelni - przyp. aut.] jest się zmęczonym w pracy - najtrudniejsze, że wszystko jest niedociągnięte - dzieci niezaopiekowane, wyspać się czy z dziećmi czas spędzić, wyścig z czasem. Dzieci tracą - czy są małe, czy starsze - każda cenna chwila ucieka. [Ewa, dwoje dzieci]

Ze względu na dzieci chciałabym, albo mniej, krócej pracować [część etatu], albo otworzyć coś swojego. Mój syn nie śpi dużo - idziemy spać o 24, a wstaję o 5, wyzwanie dla organizmu, łatwiej pogodzić pracę i wychowanie, ale jak do tego dochodzi studiowanie, to już hardkor. [Andżelika, jedno dziecko]

Byłam skrajnie przemęczona, byłam nawet zadowolona, że musiałam w końcu odejść z pracy. W miesiącu miałam 1 dzień wolny dla dziecka. (...) Moje życie rodzinne funkcjonuje po 22, kiedy mąż wraca do domu. Sam mąż przekonywał mnie do rezygnacji z pracy, żebym skończyła studia. [Małgosia, jedno dziecko]

Decyzja badanej [Małgosi], której cytat przytaczamy powyżej, jest ponownie powiązana ze swego rodzaju karą za macierzyństwo - motherhood penalty 
(Haponiuk 2014). Obowiązki związane z wychowywaniem dziecka w połączeniu ze studiami doprowadzają do wycofania się z rynku pracy. Mimo, że podjęte działania miały służyć awansowi zawodowemu, doprowadziły do rezygnacji z roli pracownika (przynajmniej tymczasowo).

Idąc dalej, to właśnie rodzicielstwo, uwarunkowane wychowywaniem dzieci w różnym wieku, wydaje się mieć wpływ na wiele decyzji związanych z pełnieniem pozostałych ról. Czasem badani postrzegali to jako element, dzięki któremu rozwijali się dalej:

To, że one są [dzieci -- przyp. autor], łatwo ustalam dzięki nim priorytety. Posiadanie dziecka ułatwiło mi decyzję, na przykład czy pojechać gdzieś, czy nie. Jest to bardzo motywujące, że nie robię tego tylko dla siebie. [Ilona, dwoje dzieci]

Gdyby nie dzieciaki, miałabym mniejszą motywację do rozwoju zawodowego, bo zwiększają się potrzeby [wynagrodzenie jest kluczowe]. Dzieciaki nauczyły mnie też planowania czasu. Teraz dwa razy bardziej zastanowię się, zanim wyjdę na 20 minut na lunch. Moja praca jest bardziej efektywna. [Marika, dwoje dzieci]

Badana podkreślała prymarność związku posiadania dzieci i trajektorii edukacyjnych oraz zobowiązań zawodowych wykazywaną również w innych badaniach (por. Carney-Crompton, Tan 2002; Stone, O'Shea 2013). Podobnie uważała Martyna:

Bo miałam licencjat, a to nie byłoby wystarczające. Zrobię tego magistra. Dla siebie, dla dzieci, żeby nie miały mamusi bez magistra. [Martyna, czworo dzieci]
Jest to o tyle ciekawe, że według badań Kotowskiej i zespołu (2007) po pojawieniu się dzieci, zmniejsza się aktywność edukacyjna rodziców. Być może należałoby się przyjrzeć, jakie są inne czynniki - poza rodzicielstwem - które wpływają na podejmowanie wyzwań edukacyjnych.

Powyższy cytat jest dobrą ilustracją internalizacji norm społecznych, jeśli chodzi o edukację. Badana dzieli się przekonaniem, że w oczach swoich dzieci mogłaby zostać odebrana jako „wybrakowana”, jeśli poprzestałaby na studiach I stopnia. Można więc powiedzieć, że w przypadku rodziców studentów poszerza się grono aktorów społecznych adresujących swoje oczekiwania społeczne i sprawujących jakąś formę kontroli społecznej właśnie o dzieci.

\section{Otoczenie ma znaczenie}

Nieunikniony konflikt jest wzmacniany lub łagodzony przez osoby ważne $\mathrm{z}$ otoczenia społecznego badanych (por. Bojarska 2017). Komentarze, jakie słyszą młodzi od bliskich, decydując się na edukację w czasie, gdy pracują i wychowują dzieci, zabarwiają dodatkowo ich narrację o zmaganiach, zwiększając intensywność odczuwania konfliktu lub łagodząc koszty godzenia ról. Część badanych jasno wskazywała na duże wsparcie, jakie otrzymali od partnerów i partnerek. Niektórzy, nie tylko zachęcali do podjęcia studiów, ale i przejmowali zadania osoby uczącej się na czas jej nieobecności, jak w poniższym przypadku:

Jestem w bardzo dobrej sytuacji, bo mój mąż w weekend miał wolne od swojej pracy i to było dla niego zupełnie naturalne, że zajmie się dziećmi [lubi to robić]. 
Rodzice i teściowie są z Warszawy [pomoc]. [Ania, dwoje dzieci]

Niemniej nie była to postawa powszechna i pojawiały się też głosy partnerów i partnerek pytających, „po co ci to” [Paweł, jedno dziecko] czy też „Moja mama całe życie się uczy. Teściowa nie rozumie tego. Uważa, że rola matki jest najważniejsza" [Iza, jedno dziecko]. Na wyzwania związane z łączeniem trzech ról niewątpliwie nakładały się tutaj oczekiwania społeczne wobec sposobu ich wypełniania. Szczególnie mocno jest to zarysowane w kontekście macierzyństwa. Co w kontekście upłciowionego rozumienia roli (Milkie, Peltola 1999; Gregory, Milner 2009) mogło znacząco wpływać na wzmocnienie konfliktu pomiędzy rodzicielstwem a pozostałymi aktywnościami.

Wydaje się, że badani byli zdeterminowani - niezależnie od oporu otoczenia - do osiągnięcia postawionych celów. Oznacza to również, że otoczenie dostrzegało lub zakładało trudności w możliwościach „dobrego" realizowania zadań związanych z rolami często stojącymi, również jego zadaniem, w opozycji do siebie (por. Gregory, Milner 2009). To, co badani już normalizowali, nie zawsze spotykało się ze zrozumieniem ich bliskich. Podobnie jak w przypadku Ilony, która słyszała pytania: „Następne? Znowu?" od najbliższej rodziny, mimo że dla niej samej kolejne studia były naturalnym uzupełnieniem drogi zawodowej. Spoglądając na dane dotyczące statusu społecznego rodziców badanych (zawód, wykształcenie), można też potwierdzić, że zrozumienie dla dalszej edukacji było mniejsze w rodzinach bez tradycji akademickich, gdzie rodzice reprezentowali klasę robotniczą oraz pracow- ników rolnictwa (por. Carney-Crompton, Tan 2002; Sadura 2018).

Badani nie wskazywali jasno na bezpośredni związek pomiędzy konfliktem ról a wsparciem otoczenia, jednak można przypuszczać, że tam, gdzie jednostka dostaje wsparcie od bliskich, jest bardziej skłonna do podejmowania różnych ról życiowych w jednym czasie, pomimo nieuniknionego wewnętrznego konfliktu tychże (por. Bojarska 2017). Otoczenie społeczne badanych było równie ważne jak sama ich postawa i to, jak odbierali swoją sytuację (por. van Rhijn, Lero 2014). Dostrzeganie trudności w łączeniu wszystkich ról bądź docenianie "dawania rady" to swoistego rodzaju nagroda, która być może nie redukuje „zmęczenia, wyrzutów sumienia” czy też „braku czasu dla rodziny”, ale jest dostrzegana. Wśród osób, które doceniły swój wysiłek i odczuwają poczucie własnej skuteczności (self-efficacy), jest Ewa:

Osobiście jestem bardzo dumna. Skończyłam [studia - przyp. aut.] z niezłym wynikiem. Dałam radę wszystko spiąć, pogodzić. [Ewa, dwoje dzieci]

Wydaje się, że było to tym bardziej dla badanej istotne, że po ukończeniu studiów pierwszego stopnia nie chciała podejmować kolejnych kroków edukacyjnych, a otoczenie nie do końca zgadzało się z jej wyborami. Mimo że potem "stała się bohaterem w rodzinie i wśród znajomych", początkowo spotkała się z dużym oporem. Niemniej odniosła sukces i dostrzegła swoje poczucie sprawstwa, które w przypadku łączenia ról przez kobiety raczej powoduje u nich efekt odwrotny (por. van Rhijn, Lero 2014). Podobną historię opowiedziała Kamila: 
Rodzice zareagowali bardzo źle na drugie studia, magisterskie. Ojciec się nie odzywał, stwierdził, że to fanaberie. Mama, że wyrzucam pieniądze męża i moje, dzieci będą zaniedbane [...] było źle. [...] Teraz się już to trochę zmienia. Przestają mnie obgadywać w kontekście edukacji, widzą moje osiągnięcia, że się da. [Kamila, dwoje dzieci]

W tej historii dużą rolę odegrali przełożeni w pracy, którzy wyrazili swój szacunek dla łączenia ról. Możemy tutaj obserwować konstruowanie innych oczekiwań wobec ról pełnionych przez badaną, $\mathrm{w}$ zależności od tego, czy $\mathrm{w}$ relacji $\mathrm{z}$ otoczeniem jest ona członkinią rodziny, czy też pracownicą. Tam, gdzie rodzina dostrzegała straty i oczekiwała większego zaangażowania, przełożeni widzieli zyski i przyszły zwrot z inwestycji. Role były konstruowane $\mathrm{w}$ relacji do punktu odniesienia. Wiązało się to z tym, że, jak sama Kamila stwierdziła, nie bierze wolnego, „normalnie pracuje”, czyli tak naprawdę podjęcie studiów czy rodzicielstwo nie wpływają bezpośrednio na pracę. Obrazowo czas nakładania się na siebie wielu istotnych ról życiowych i związane z nim wyzwania podsumowuje Paweł [jedno dziecko]: „Rodzicielstwo, praca i studia jest jak gra komputerowa, jak opanujesz jednej poziom, nagle robi się dwa razy trudniej”. Młodzi więc grają w tę grę, zmagając się z wyzwaniami na różnych jej poziomach.

\section{Wnioski}

Kontekstem teoretycznym tego rozważania był konflikt ról, do jakiego dochodzi współcześnie na wczesnych etapach dorosłości. W artykule wykazano wyraźne sprzężenie między trzema główny- mi obszarami życia młodych Polaków, to jest pracą, rodziną oraz edukacją. Wydaje się, że wymogi współczesnego świata wyraźnie ukierunkowują młodych dorosłych na łączenie edukacji z praca, co pokazują tak dane statystyczne o jednocześnie pracujących i studiujących (GUS 2011; 2017; Eurofound 2014), jak i wcześniejsza edycja badania jakościowego absolwentów Uniwersytetu SWPS (Sarnowska in. 2016).

Łączenie studiów z pracą zawodową stało się zjawiskiem znormalizowanym, niebudzącym szczególnego zdziwienia, choć oczywiście rodzi różnorodne wyzwania. Współcześnie zdobycie wyższego wykształcenia nie jest przyczynkiem do awansu zawodowego, stało się za to elementem zmniejszającym ryzyko zasilenia grupy bezrobotnych - młodych (Jelonek i in. 2015). Dodanie kolejnego wymiaru, to jest wychowywania dzieci, do już wypełnionego $\mathrm{w}$ pełni pracą i nauką harmonogramu, powoduje znaczące nasilenie odczuwanego przez badanych konfliktu ról. Szczególnie znaczące jest nakładanie się dyskursów dotyczących dobrego rodzicielstwa z praktycznymi zobowiązaniami wobec innych wymiarów życia (por. Home 1997; Kotowska i in. 2007; Pustułka, Ślusarczyk 2016).

Asynchroniczność sekwencji biograficznych respondentów, która oznacza zmiany związane z wchodzeniem w dorosłość i wielowymiarową raczej niż jednorazową tranzycją, zamazuje odrębność poszczególnych ról i ich naturalne następowanie po sobie. Jednocześnie tak badanie własne, jak i szersze badania polskie nie rozstrzygają jednoznacznie pozytywnego bądź negatywnego wpływu rodzicielstwa na podejmowanie i kończenie 
sukcesem wyzwań edukacyjnych. Można podejrzewać, że, zgodnie z ustaleniami międzynarodowymi (Scott i in. 1996; Tones i in. 2009; Stone, O'Shea 2013), centralizacja roli matki może wpływać demotywacyjnie i obniżać poziom osiąganych wyników. Jednocześnie wydaje się, że w Polsce istotne czy wręcz decydujące $w$ tym zakresie będą również inne elementy, którym warto byłoby się bliżej przyjrzeć, takie jak sytuacja ekonomiczna, wsparcie otoczenia czy kapitał kulturowy nabyty w domu rodzinnym, a także stereotypy dotyczące kobiecości, macierzyństwa i troski (por. Kotowska 2007; Titkow 2007).

Omawiana szeroko „chciwość” kluczowych dla życia jednostek instytucji społecznych (Coser 1974; Hochschild 1997; Home 1997) jest ograniczana przez nie same, jeśli widzą potencjalne korzyści w przyszłości.

Jak wykazano w analizie, prymarna rola rodzicielska jest zawsze zarzewiem konfliktów między obszarami pracy, edukacji i domu (por. Home 1997; Kotowska 2007; Tones i in. 2009; Pustułka, Ślusarczyk 2016). Na podstawie analizy zgromadzonego materiału stwierdzamy, że zdobywanie dyplomu - na poziomie wyższym czy to doktorskiego - znacząco wzmacnia - czy też zwielokrotnia - poczucie skonfliktowania ról zawodowych i rodzinnych. Napięcia wynikające z konfliktu ról są niwelowane na różne sposoby w zależności od zasobów ekonomicznych: część respondentów niejako „wykupywała” się z roli pracownika, ograniczając zarobkowanie i poświęcając się rolom edukacyjnym i rodzinnym. Respondentki z mniejszym kapitałem edukacyjnym stale odczuwały silny konflikt, często oceniając realizację przez siebie każdej z ról jako nieoptymalną, to jest twierdziły, że nie były wystarczająco dobrymi rodzicami, że nie wywiązywały się w pełni z obowiązków zawodowych oraz, że studia traktowały instrumentalnie, po to tylko, aby uzyskać dyplom jak najmniejszym wysiłkiem.

Upłciowiony charakter konfliktu oznacza, że zdecydowanie najmocniej konflikt ról odczuwają kobiety w odniesieniu do roli matki, której „chciwość” oraz powiązane odczuwanie odpowiedzialności społecznej i osobistej za dzieci nie pozwalają respondentkom na satysfakcjonującą realizację ról zawodowych oraz studenckich. Jednocześnie w narracji mężczyzn spotykamy się raczej z podejściem zadaniowym i „umownym”, w którym respondenci zawierali ze swoimi partnerkami kontrakt dotyczący podjęcia roli studenta. Mężczyźni przyjmują, że w czasie pełnienia tej roli zajmują się przede wszystkim studiowaniem i domem, a nie rodziną. Stoją tu w wyraźnej opozycji do kobiet, które organizują życie rodzinne niezależnie od konfliktu.

Warto dodać, że pracownik-student-rodzic to nie jedyne role, które wpływały na odczuwanie konfliktu. Istotni inni, czyli partnerzy (żony/mężowie) i rodzice oraz przyjaciele respondentów mogli niwelować za pomocą wsparcia konflikty studia-dom lub - w przypadku negatywnej oceny podejmowanej aktywności edukacyjnej - jeszcze nasilać konflikt, sugerując, że student-rodzic-pracownik nie wywiązuje się także z innych ról, na przykład córki/syna czy żony/męża.

Jednocześnie, mimo dużego obciążenia czasowego i organizacyjnego oraz znacznego odczuwania konfliktu ról, badani, a zwłaszcza badane otrzymują 
„nagrody” od otoczenia oraz w zakresie samooceny. Nabierają poczucia sprawczości i przekonania o własnej skuteczności (van Rijn, Lero 2014), a swoje rodzicielstwo postrzegają jako element, który raczej skłania ich do podejmowania nowych wyzwań, a nie jako element blokujący.

Wyzwania wynikające z konfliktu ról badanych są jednocześnie wskazówkami dla uczelni wyższych, które budują swoje strategie na podstawie analizy zmieniającego się dynamicznie otoczenia organizacji. Realizacja różnorodnych form wspar-

\section{Bibliografia}

Anielska Agnieszka (2017) Edukacja dorostych w ofercie szkót wyższych. Strategie uczelni w świetle teorii zależności od zasobów. „Edukacja”, t. 3, nr 142, s. 94-108.

Arnett Jeffrey Jensen (2014) Emerging adulthood: The winding road from the late teens through the twenties. New York: Oxford University Press.

Bobrowicz Barbara (2007) Alokacja czasu: praca zawodowa i edukacja versus funkcje opiekuńcze i prace domowe [w:] Irena E. Kotowska, Urszula Sztanderska, Irena Wóycicka, red., Aktywność zawodowa i edukacyjna a obowiazki rodzinne w Polsce: w świetle badań empirycznych. Warszawa: Scholar, s. 81-131.

Bojarska Anna (2017) Przeżywanie macierzyństwa podjętego w trakcie studiów na przykładzie studentek lubelskich uczelni. „Roczniki Pedagogiczne”, t. 6, nr 3, s. 69-93.

Carney-Crompton Shawn, Tan Josephine (2002) Support systems, psychological functioning, and academic performance of nontraditional female students. "Adult Education Quarterly”, vol. 52, no. 2 , s. $140-154$.

Chung Ethel, Turnbull Deborah, Chur-Hansen Anna (2014) Who are 'non-traditional students'? A systematic review of published cia, jakiego potrzebują studenci łączący pracę/rodzicielstwo z edukacją, może stać się elementem wyróżniającym uczelnię i zwiększającym jej szanse na pozyskanie nowych studentów i utrzymanie absolwentów w perspektywie zbliżającego się niżu demograficznego (Anielska 2017). Biografie respondentów uwypuklają nakładanie się ról w jednym czasie i pojawiające się w związku z tym wyzwania. Nieunikniony konflikt ról na polu trzech wrażliwych sfer życia młodych, zaliczanych do "chciwych instytucji”, przybiera nowy i wielowymiarowy obraz.

definitions in research on mental health of tertiary students. „Educational Research and Reviews", vol. 9, no. 22, s. 1224-1238.

Coser Lewis A. (1974) Greedy institutions; patterns of undivided commitment. New York: The Free Press.

Currie Jan, Harris Patricia, Thiele Bev (2000) Sacrifices in greedy universities: are they gendered? "Gender and Education", vol. 12, no. 3, s. 269-291.

Dahrendorf Ralf (1973) Homo Sociologicus. London: Routledge and Kegan Paul.

Eurofound (2014) Mapping youth transitions in Europe. Luxembourg: Publications Office of the European Union [dostęp 15 czerwca 2017 r.]. Dostępny w Internecie: https://www.eurofound.europa.eu/publications/ report/2014/labour-market/mapping-youth-transitions-in-europe».

Eurostat (2018a) Population by educational attainment level, sex and age main indicators [dostęp 7 października 2018 r.]. Dostępny w Internecie: http://appsso.eurostat.ec.europa.eu/nui/submitViewTableAction.do».

Eurostat (2018b) EU Indicators in the Field of Youth [dostęp 15 maja 2018 r.]. Dostępny w Internecie: ‘http://ec.europa.eu/eurostat/web/youth/data/eu-dashboard. 
Fenton Steve, Dermott Esther (2006) Fragmented careers? Winners and losers in young adult labour markets. „Work, Employment and Society", vol. 20, no. 2, s. 205-221.

Furlong Andy (1992) Growing up in a classless society? School to work transitions. Edinburgh: Edinburgh University Press.

Goffman Erving (2011) Człowiek w teatrze życia codziennego. Przełożyli Paweł Śpiewak, Helena Datner-Śpiewak. Warszawa: Wydawnictwo Naukowe PWN.

Goode William J. (1960) A Theory of Role Strain. „American Sociological Review", vol. 25, no. 4, s. 483-496.

Grabowska-Lusińska Izabela (2012) Raport końcowy z monitoringu losów zawodowych absolwentów. [niepublikowany komputeropis].

Gregory Abigail, Milner Susan (2009) Editorial: work-life balance: a matter of choice? "Gender, Work \& Organization”, vol. 16, no. 1, s. $1-13$.

GUS (2011) Wejście ludzi młodych na rynek pracy w Polsce w 2009 r. [dostęp 16 sierpnia 2015 r.]. Dostępny w Internecie: ‘http://stat. gov.pl/obszary-tematyczne/rynek-pracy/opracowania/wejscieludzi-mlodych-na-rynek-pracy-w-polsce-w-2009-r-,2,1.html».

GUS (2013) Kształcenie dorostych 2011 [dostęp 8 maja 2018 r.]. Dostępny w Internecie: ‘https://stat.gov.pl/obszary-tematyczne/ edukacja/edukacja/ksztalcenie-doroslych-2011,3,2.html».

GUS (2016) Mał̇̇enstwa oraz dzietność w Polsce [dostęp 16 maja 2018 r.] Dostępny w Internecie: 〈https://stat.gov.pl/files/gfx/ portalinformacyjny/pl/defaultaktualnosci/5468/23/1/1/malzenstwa_i_dzietnosc_w_polsce.pdf .

GUS (2017) Osoby młode na rynku pracy w 2016 r. [dostęp 8 maja 2018 r.]. Dostępny w Internecie: ‘https://stat.gov.pl/files/gfx/portalinformacyjny/pl/defaultaktualnosci/5821/13/1/1/osoby_mlode_na_rynku_pracy_w_2016r.pdf`https://stat.gov.pl/files/gfx/ portalinformacyjny/pl/defaultaktualnosci/5821/13/1/1/osoby_ mlode_na_rynku_pracy_w_2016r.pdf .

GUS (2019) Szkolnictwo wyższe w roku akademickim 2018/2019 (wyniki wstępne) [dostęp 25 października 2019 r.]. Dostępny w Inter- necie: https://stat.gov.pl/obszary-tematyczne/edukacja/edukacja/ szkolnictwo-wyzsze-w-roku-akademickim-20182019-wynikiwstepne,8,6.html.

Haponiuk Marzena (2014) Sytuacja kobiet na rynku pracy w Polsce. „Zeszyty Naukowe”, nr 1, s 38-51.

Hochschild Arlie R. (1997) The Time Bind. When Work becomes Home and Home Becomes Work. New York: Metropolitan Books.

Home Alice M. (1997) Learning the hard way: Role strain, stress, role demands, and support in multiple-role women students. "Journal of Social Work Education", vol. 33, no. 2, s. 335-347.

Inglot-Brzęk Elżbieta (2012) Przemiany demograficzne a rozwój szkolnictwa wyższego w Polsce. „Nierówności społeczne a wzrost gospodarczy", t. 26, s. 216-229.

Jelonek Magdalena, Antosz Patrycja, Balcerzak-Raczyńska Anna (2014) Przyszłe kadry polskiej gospodarki. Na podstawie badań studentów oraz analizy kierunków kształcenia zrealizowanych w 2013 roku w ramach IV edycji projektu Bilans Kapitału Ludzkiego [dostęp 15 maja 2018 r.]. Dostępny w Internecie: https://www. parp.gov.pl/storage/publications/pdf/20014.pdf.

Jelonek Magdalena, Kasparek Krzysztof, Magierowski Mateusz (2015) Młodzi na rynku pracy-pracownicy, przedsiębiorcy, bezrobotni: na podstawie analizy kierunków ksztatcenia zrealizowanej w 2014 roku w ramach $V$ edycji projektu Bilans Kapitału Ludzkiego [dostęp 10 maja 2018 r.]. Dostępny w Internecie: ‘http://www.uj.edu.pl/ documents/102715934/2e0bba6c-e1e6-4248-8a4e-443f8573fca0).

Konecki Krzysztof T. (2018) Problem ontologicznej niepewności. Czego możemy się nauczyć od socjologii dzisiaj? Inspiracje buddyzmem zen. „Przegląd Socjologii Jakościowej”, t. 14, s. 50-83.

Kotowska Irena E. (2007) Sytuacja kobiet powracajacych na rynek pracy po przerwie spowodowanej macierzyństwem i opieka nad dzieckiem [w:] Julian Auleytner, red., Wieloaspektowa diagnoza sytuacji kobiet na rynku pracy. Raport końcowy. EFS, SPO RZL 1.6(b). Warszawa: Ministerstwo Pracy i Polityki Społecznej, s. 30-45.

Kotowska Irena E., Sztanderska Urszula, Wóycicka Irena, red., (2007) Aktywność zawodowa i edukacyjna a obowiazki rodzinne w Polsce: $w$ świetle badań empirycznych. Warszawa: Scholar. 
Liberska Hanna (2007) Współczesny obraz moratorium [w:] Barbara Harwas-Napierała, Hanna Liberska, red., Tożsamość a wspótczesność. Nowe tendencje i zagrożenia. Poznań: Wydawnictwo Naukowe UAM, s. 25-52.

Litwiński Jacek (2007) Aktywność edukacyjna [w:] Irena E. Kotowska, Urszula Sztanderska, Irena Wójcicka, red., Aktywność zawodowa i edukacyjna a obowiazki rodzinne w Polsce: $w$ świetle badań empirycznych. Warszawa: Scholar, s. 219-238.

Marshall Gordon, ed., (1998) A dictionary of sociology. Oxford: Oxford University Press.

Milkie Melissa A., Peltola Pia (1999) Playing all the roles: Gender and the work-family balancing act. "Journal of Marriage and the Family", vol. 61, no. 2, s. 476-490.

Neale Bren i in. (2015) Researching the lives of young fathers: The following Young Fathers Study \& Dataset. „Following Young Fathers Briefing Paper No. 8", s.1-71.

Orczykowska Anna (2016) Szkolnictwo wyższe a wymagania rynku pracy. „Nauka i Szkolnictwo Wyższe”, t. 28, nr 2, s. 49-64.

Parsons Talcott (2009) System społeczny. Przełożył Michał Kaczmarczyk. Kraków: Zakład Wydawniczy NOMOS.

\section{Pustułka Paula, Ślusarczyk Magdalena (2016) Work-} -life balance in the Polish migrant families settled in Norway. "Miscellanea Anthropologica et Sociologica", t. 17, nr 3, s. 71-91.

Ricco Robert, Sabet Sarah, Clough Cassandra (2009) College mothers in the dual roles of student and parent: Implications for their children's attitudes toward school. „Merrill-Palmer Quarterly”, vol. 55, no. 1, s. 79-110.

Rosińska-Kordasiewicz, A. (2008). Stużaca, pracownik, domownik. Polki jako pomoce domowe w Neapolu w kontekście retradycjonalizacji instytucji. „Kultura i Społeczeństwo”, t. 52, nr 2.

Ruszkiewicz Dorota (2012) Macierzyństwo w czasie studiów. „Pedagogika Rodziny", t. 2, nr 4, s. 175-187.

Sadura Przemysław (2018) Państwo, szkoła, klasy. Warszawa: Wydawnictwo Krytyki Politycznej.
Sarnowska Justyna, Grabowska Izabela (2018) Pracująco-studiujący. Przejście z edukacji do zatrudnienia socjologów i kulturoznawców na przykładzie prywatnego uniwersytetu w Polsce. "Górnośląskie Studia Socjologiczne. Seria Nowa”, t. 9, s. 47-62.

Sarnowska Justyna, Winogrodzka Dominika, Pustułka Paula (2018) The changing meanings of work among university-educated young adults from a temporal perspective. "Przegląd Socjologiczny/ Sociological Review", vol. 67, no. 3, s. 111-134.

Sarnowska Justyna i in. (2016) Łaczenie edukacji z praca jako wyznacznik wspótczesnego pokolenia młodych dorostych w potransformacyjnej Polsce? „Prace o Młodych / Youth Working Papers”, 1/2016, s. 1-48.

Scott Catherine, Burns Ailsa, Cooney George (1996) Reasons for discontinuing study: The case of mature age female students with children. „Higher education”, vol. 31, no. 2, s. 233-253.

Settersten Richard A. Jr. (2007) Passages to adulthood: Linking demographic change and human development. „European Journal of Population", vol. 23, no. 3-4, s. 251-272.

Slany Krystyna (2013) Zagadnienia małżeństwa i rodzin w perspektywie feministyczno-genderowej. Kraków: Wydawnictwo Uniwersytetu Jagiellońskiego.

Slany Krystyna, Krzaklewska Ewa, Warat Marta (2016) Wzory życia rodzinnego w kontekście równości ptci: między tradycja a partnerstwem [w:] Iwona Przybył, Aldona Żurek, red., Role rodzinne. Między przystosowaniem a kreacją. Poznań: Wydawnictwo UAM, s. 77-96.

Stone, Catherine, O'Shea Sarah Elizabeth (2013) Time, money, leisure and guilt-the gendered challenges of higher education for mature-age students. „Australian Journal of Adult Learning”, vol. 53 no. 1 , s. 95-116.

Szafraniec Krystyna (2012) Młodość jako wyłaniajacy się problem i nowa polityczna siła. „Nauka”, t. 1, s. 101-122.

Szafraniec Krystyna i in. (2017) Zmiana warty. Młode pokolenie a transformacje we wschodniej Europie i Azji. Warszawa: Scholar.

Szulc Tadeusz (2016) Dynamika przemian w szkolnictwie wyższym $w$ Polsce a realizacja procesu bolońskiego. „Nauka i Szkolnictwo Wyższe", t. 24, nr 2, s. 7-36. 
Titkow Anna (2007) Tożsamość polskich kobiet: Ciagłość, zmiana, konteksty. Warszawa: Wydawnictwo IFiS PAN.

Tones Megan i in. (2009) Supporting mature-aged students from a low socioeconomic background. „Higher Education”, vol. 58, no. 4 , s. 505-529.

Van Rhijn Tricia M. (2014) Barriers, enablers, and strategies for success identified by undergraduate student parents. "Canadian Journal for New Scholars in Education”, vol. 5, no. 1, s. 1-11.
Van Rhijn Tricia M., Lero Donna S. (2014) The influence of self-efficacy beliefs for student parents attending university. „International Journal of Lifelong Education”, vol. 33, no. 4, s. 541-555.

Wrzesień Witold (2016) Kilka uwag o pokoleniowej sytuacji wspótczesnej polskiej młodzieży. „Ruch Prawniczy, Ekonomiczny i Socjologiczny", t. 78, nr 1, s. 229-241.

Wyn Joanna, Dwyer Peter (1999) New directions in research on youth in transition. "Journal of youth studies", vol. 2(1), s. 5-21.

\title{
Cytowanie
}

Mleczko Izabela i in. (2019) Nowe oblicza konfliktu ról wśród młodych Polek i Polaków w świetle łączenia rodzicielstwa ze studiami i praca zawodowa. „Przegląd Socjologii Jakościowej”, t. 15, nr 4, s. 106-129 [dostęp dzień, miesiąc, rok]. Dostępny w Internecie: 〈www.przegladsocjologiijakosciowej.org〉. DOI: http://dx.doi.org/10.18778/1733-8069.15.4.06.

\section{The New Faces of Role Conflicts among Young Polish Polish in the Context of Combining Parenting with University Education and Employment}

\begin{abstract}
This article discusses combining parenthood and the practice of parenting with university education and work. The situation of experiencing the overlap of the roles of a mother/father, an employee, and a student constitutes a specific exemplification of challenges and role conflicts experienced by young people who seek to manage social contexts that are mutually competitive. These young people's situation results from the broader social context wherein pursuing university degrees is extremely typical of young Polish men and women, while the student population encompasses both parents and people with established careers. The empirical material used for this article stems from a qualitative study conducted in 2017 and 2018. The material for the article comprises 30 analysed interviews with students and alumni who - at the time of the research - were combining parenthood with both work and university education. The respondents had at least one child aged 0 to 15 whilst actively pursuing a degree. The results show the existence of role conflicts and reveal that the conflicts vary and depend on social factors such as gender, social support, and institutional assistance. The role conflicts are strictly tied to the 'greedy institutions' notion applied to education, parenting, and employment. A certain normalization of combining all three aspects within a single biographical timeline was observed, with a concurrent outcome of respondents having strong desires to be successful across all those fields.
\end{abstract}

Keywords: role conflict, young people, transition from education to work, parenthood 